\title{
Polyacrylamide gel disc electrophoresis of alkaline phosphatase isoenzymes in bone and liver disease
}

\author{
T. W. WARNES, P. HINE, AND G. KAY \\ From the Department of Gastroenterology, Manchester Royal Infirmary, Manchester MI3 9WL
}

SYNOPSIS Acrylamide gel disc electrophoresis provides a reliable and reasonably rapid method of differentiating the raised serum alkaline phosphatase (AP) of bone origin from that of liver origin. The technique has been placed for the first time on a semiquantitative basis. Measurement of both band width and band position effectively distinguishes the bone from the liver isoenzyme, but band width provides superior discrimination.

An origin band was seen in none of the normal subjects and in only $7 \%$ of patients with bone disease but was present in $78 \%$ of patients with liver disease, a highly significant increase. Fifty percent of normal individuals had a small-intestinal band in serum taken two hours after a meal, $\vec{c}$ as did $35 \%$ of patients with liver disease, but the incidence of intestinal bands in bone disease was only $11 \%$, significantly less than in the other two groups. The genetic control of small-intestinal AP in serum has been confirmed, but it has been demonstrated that the decrease of intestinal AP in bone disorders is not genetically determined.

Following the first demonstration that serum alkaline phosphatase (EC 3.1.3.1) exists in more than one form, many attempts have been made to determine the organ source of this enzyme in health and disease by means of electrophoresis on a variety of media including paper, agar gel, cellulose acetate, starch gel, Pevikon C-870, and, more recently, acrylamide gel (Warnes, 1972). Most of these electrophoretic techniques reveal bone and liver components which are thought to comprise the main band, together with a third isoenzyme which is present in some individuals and which is identical with intestinal alkaline phosphatase, while a fourth isoenzyme which remains at the origin is frequently found in patients with liver disease. The results obtained by different techniques have often been conflicting. Thus some workers have claimed that the differentiation between bone and liver alkaline phosphatase can be made on the basis of the minor bands (Chiandussi et al, 1962). In contrast, other workers have claimed to make the distinction between bone and liver enzymes by the position of the major bands, the liver band running slightly ahead of the bone band (Newton, 1967). The recent advent of polyacrylamide gel electrophoresis has been claimed to produce a clear and constant difference in both mobility and shape between the bone and liver

Received for publication 30 December 1975 bands (Smith et al, 1968; Walker and Pollard, 1971 However, even the use of this technique has yielded conflicting results. Kaplan and Rogers (1969) reported that, in their series, four patients with bone disease alone had a liver type main band, and in two of these there was no reason to suspect liver disease, while Sussman et al (1968) found that the AP isoenzymes of liver, bone, kidney, and intestine all moved with indistinguishable mobilities. More recently, Afonja and Baron (1974) found that normal adult serum always contained a slow 'liver' band and sometimes a bone band. Many of the discrepancies are accounted for by the fact that interpretation of the results obtained by electrophoretic separation of the alkaline phosphatase isoenzymes in serum has until now been largely

subjective.
We have therefore placed the technique of acrylamide gel disc electrophoresis of serum alkaline $\bar{N}$ phosphatase isoenzymes for the first time on a semiquantitative basis. This has permitted the results $N$ obtained to be analysed statistically. Although intestinal alkaline phosphatase has been identified in serum electrophoretically, the incidence of gut 0 bands in health and disease is a subject of controversy. Kaplan and Rogers (1969) found an intestinal band $\stackrel{\oplus}{+}$ in fasting serum in only 2 out of 135 patients with a 7 variety of bone and liver disorders, while Langman et al (1966) reported that up to $60 \%$ of normal 
human sera contained a small-intestinal band on electrophoresis. The finding of raised levels of intestinal alkaline phosphatase in serum has been reported in cirrhosis of the liver (Fishman et al,1965), but estimation of this isoenzyme in osteoblastic bone disease has not previously been reported.

\section{Material and methods}

The normal group comprised 28 healthy medical students with a mean AP of 4.8 King-Armstrong (KA) units/dl (table I). The liver disease group, which comprised 68 patients with proven liver disease and a raised serum AP, had a mean AP of $35.5 \mathrm{KA}$ units/dl. The diagnosis of liver disease was based on clinical and laboratory findings, supplemented in most cases by liver biopsy, laparotomy or necropsy findings. The bone disease group consisted of 27 patients with a variety of osteoblastic bone disorders who had a mean AP of $35 \cdot 2 \mathrm{KA}$ units/dl. Several months after the electrophoresis had been completed, the hospital records were reviewed and the definitive diagnoses were recorded.

All blood samples were taken two hours after a hospital meal containing between 20 and $\mathbf{4 0} \mathrm{g}$ fat. The assay procedure for alkaline phosphatase was the Kind-King modification of the King-Armstrong method (Kind and King, 1954). For a single estimation the $95 \%$ confidence limits were activity \pm $2-3 \%$.

Samples of serum were subjected to disc electrophoresis in a Shandon electrophoresis tank (Shandon Scientific Co Ltd, London) using a $5 \%$ polyacrylamide gel and a continuous buffer system (tris-borate buffer, $\mathrm{pH} \mathrm{9.5),} \mathrm{the} \mathrm{method} \mathrm{being} \mathrm{basically} \mathrm{that} \mathrm{of}$ Smith et al (1968). A $100 \mu \mathrm{l}$ aliquot of serum was mixed with $200 \mu \mathrm{l}$ of $20 \%$ sucrose, and $20 \mu \mathrm{l}$ of this mixture was applied to the gel. Electrophoresis was

\begin{tabular}{llc}
\hline Group & No. & Mean AP $\pm 1 S D$ \\
\hline Normal & 28 & $4 \cdot 8 \pm 1 \cdot 4$ \\
Liver $^{2}$ & 68 & $35 \cdot 5 \pm 28 \cdot 2$ \\
Bone $^{2}$ & 27 & $35 \cdot 2 \pm 22 \cdot 3$
\end{tabular}

Table I Composition of the normal, liver, and bone disease groups

AP results are in King-Armstrong units/d1

${ }^{1}$ Cirrhosis of the liver (6), hepatitis (8), stones in the common bile duct (4), carcinoma of the extrahepatic bile ducts (2), primary carcinoma of the liver (3), secondary carcinoma of the liver (10), carcinoma of the gall bladder (1), carcinoma of the head of the pancreas (8), primary biliary cirrhosis (9), infiltrations of the liver (3), intrahepatic cholestasis (8), cholangiohepatitis (4), and gallstones (2)

${ }^{2}$ Composed of 14 with Paget's disease of bone diagnosed on $x$-ray, 7 with osteomalacia diagnosed by $x$-ray and bone biopsy, 3 with rickets diagnosed clinically, biochemically and radiologically, 2 with hyperparathyroidism confirmed at operation, 1 with renal osteodystrophy continued until the bromphenol blue-albumin complex of a reference serum had reached the end of the index gel, the length of which was approximately $65 \mathrm{~mm}$. The enzyme bands were located by a diazo-coupling technique, using $\beta$-naphthyl phosphate and Fast Blue BB. Band width was measured on serum diluted to give an AP value of 10-15 KA units/dl since preliminary observations showed that for any given serum an increased AP level resulted in an increase in band width. Each serum was also run undiluted, and the position of the bands on the gel was measured in millimetres from the origin. All measurements were made with a ruler to the nearest $0.5 \mathrm{~mm}$. Band width and position were then expressed as a percentage of the length of the index gel, so producing modified ' $R_{i}$ ' values which could then be subjected to statistical analysis. The coefficient of variation for duplicates within a run was $1.6 \%$, and between runs was $2.0 \%$. All observations on intestinal AP were made on the undiluted sera.

The nature of the origin band was further investigated by gel filtration using Sephadex G200. Twomillilitre samples of serum obtained from a patient with obstructive jaundice were applied to a column $2.5 \mathrm{~cm} \times 40 \mathrm{~cm}$ which was equilibrated with a tris-saline buffer, pH 8.0 (Tris $50 \mathrm{mmol} / \mathrm{l}, \mathrm{NaCl}$ $100 \mathrm{mmol} / \mathrm{l}$, adjusted with $\mathrm{HCl} 1 \mathrm{~mol} / \mathrm{l}$ ). Twomillilitre fractions were collected at a flow rate of $30 \mathrm{ml}$ per hoúr, and the fractions were first assayed for alkaline phosphatase activity and then subjected to electrophoresis.

The ABO blood group and secretor status of each individual were determined by standard techniques (Dunsford and Bowley, 1967; Dacie and Lewis, 1968).

\section{Results}

On acrylamide gel disc electrophoresis intestinal and origin bands were seen in addition to the main band (fig 1). The main band seen in bone disease was diffuse and ran slightly behind the more compact liver band, while two main bands were always found in normal serum.

The main liver band was significantly faster than the bone band (table II); the faster band of normal serum (band I) did not differ significantly in position from the main liver band, and the slower band (band II) did not differ significantly in position from the bone band. The difference in width between the bone and liver bands was highly significant. Although there was a significant difference in both mean position and mean width, there was considerable overlap as regards position between the bone and liver bands (fig 2). Band width was a better dis- 
T. W. Warnes, P. Hine, and G. Kay $\stackrel{\complement}{\mathrm{C}}$

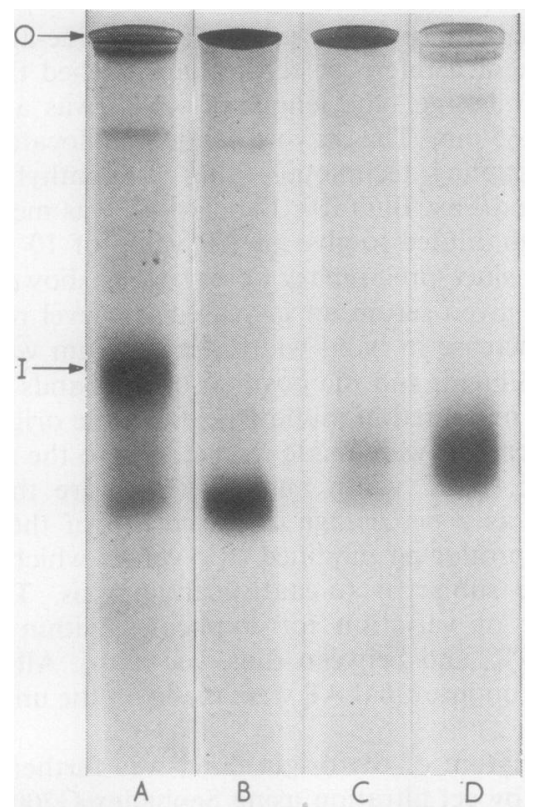

\begin{tabular}{|c|c|c|}
\hline & Position & Width \\
\hline $\begin{array}{l}\text { Liver disease } \\
\text { Normal (band I) } \\
\text { Normal (band II) } \\
\text { Bone disease }\end{array}$ & $\begin{array}{l}60 \cdot 3 \pm 3 \cdot 4 \\
61 \cdot 4 \pm 3 \cdot 0 \\
56 \cdot 7 \pm 2 \cdot 6 \\
57 \cdot 1 \pm 2 \cdot 5\end{array}$ & $3 \cdot 3 \pm 0.9$ \\
\hline $\begin{array}{l}\text { Student's t test } \\
\text { Liver } v \text { bone } \\
\text { Liver } v \text { normal I } \\
\text { Bone } v \text { normal II } \\
\text { Liver } v \text { normal II } \\
\text { Bone } v \text { normal I }\end{array}$ & $\begin{array}{l}P<0.001 \\
\text { NS } \\
\text { NS } \\
P<0.001 \\
P<0.001\end{array}$ & $\mathbf{P}<0.001$ \\
\hline
\end{tabular}

Table II Band width and position for normal, bone, and liver groups

Results are given as mean $\pm 1 \mathrm{SD}$

peaks of activity showed the $19 \mathrm{~S}$ protein-like peak to contain the origin band while the $7 \mathrm{~S}$ protein-likepeak contained the main liver band (fig 3).

\section{BLOOD GROUPS}

The influence of the ABO blood group of a normalcs individual in determining the level of AP in hiso serum is seen in table IV. Normal subjects of blood $\stackrel{\mathbb{D}}{3}$

Fig 1 Electrophoresis of serum alkaline phosphatase: (A) liver disease, main band with intestinal band (I); (B) liver disese, main band with origin band $(\mathrm{O}) ;(\mathrm{C})$ normal serum; (D) bone disease. The band at the origin for normal serum $(\mathrm{C})$ is a non-specific protein band and not AP.

criminant since there was virtually no overlap between bone and liver.

\section{INTESTINAL BANDS}

Fifty per cent of normal individuals were found to have a small-intestinal band in serum taken two hours after a meal, as also did $35 \%$ of patients with liver disease (table III). However, in the bone disease group the incidence of gut bands was only $11 \%$, which is significantly less than in the other two groups.

\section{ORIGIN BANDS}

Table III also shows the incidence of origin bands in the three groups. The origin band was absent in all normal subjects, and was found in only $7 \%$ of patients with osteoblastic bone disease. It was, however, present in $78 \%$ of the patients with liver disease, a highly significant increase compared with the other two groups.

\section{GEL FILTRATION}

When serum from patients with liver disease was subjected to gel filtration, two peaks of AP activity were obtained. One eluted in the same peak as the $19 \mathrm{~S}$ proteins and the other in the same peak as the $7 \mathrm{~S}$ proteins. Subsequent electrophoresis of the two group $\mathrm{O}$ or B have higher total levels of AP than those of blood group A, while within a given blood $\stackrel{\mathbb{}}{-}$ group there was a tendency for individuals who $\overrightarrow{0}$ were secretor positive to have higher levels of spd than those who were secretor negative, the mean? for group $O$ secretor positive being 5.7 and group $O$ secretor negative $4.4 \mathrm{KA}$ units/dl. On

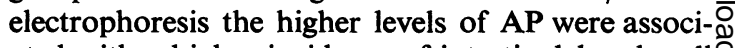
ated with a higher incidence of intestinal bands, all seven subjects of blood group $O$ who were secretor $\stackrel{\varrho}{\Rightarrow}$ positive having an intestinal band. In five of these $\overrightarrow{\overrightarrow{0}}$ the band was of medium intensity, and in two it was strong. In contrast, of the 10 normals who were? group A secretor positive, only three showed an intestinal band.

In the bone group, however, genetic control: appeared to be lost, since patients with blood group? $O$ had a lower mean AP than those of blood group $A$, and even when groups $O$ and $B$ were combined there was no significant difference between the mean 0 AP of the combined group and that of patients with bone disease who were blood group A (table IV).

The distribution of blood groups observed in the normal, bone, and liver groups is summarized in $\mathrm{N}$ table V. These figures are compared with the N numbers which would be expected for the UKN population (Kopec, 1970). It can be seen that in ${ }_{0}^{\omega}$ each group there is no significant difference between the observed and the expected values.

\section{Discussion}

This work helps to explain the discrepancies in the 


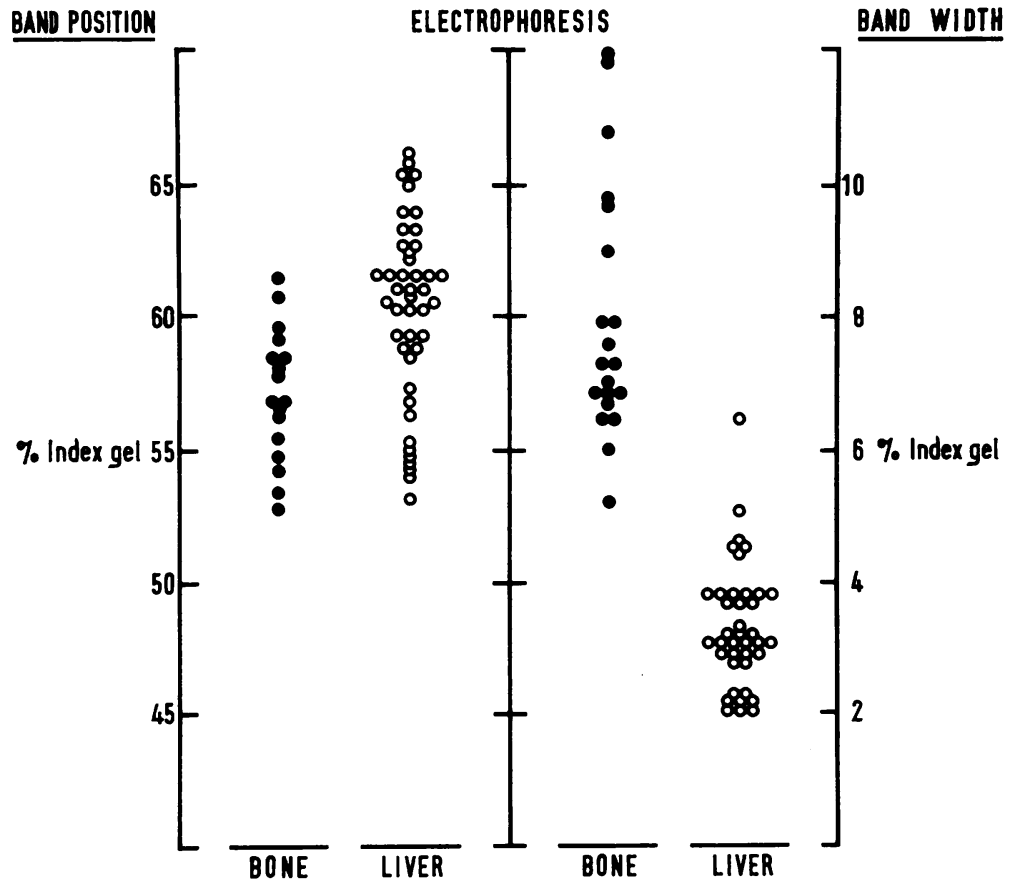

Fig 2 Band width and position on electrophoresis.

\begin{tabular}{|c|c|c|c|c|c|}
\hline \multirow[t]{2}{*}{ Group } & \multirow[t]{2}{*}{ No. } & \multicolumn{2}{|c|}{ Intestinal Bands } & \multicolumn{2}{|c|}{ Origin Bands } \\
\hline & & No. Obs. & Percent & No. Obs. & Percent \\
\hline $\begin{array}{l}\text { Normal } \\
\text { Bone } \\
\text { Liver }\end{array}$ & $\begin{array}{l}28 \\
27 \\
68\end{array}$ & $\begin{array}{r}14 \\
3 \\
24\end{array}$ & $\begin{array}{l}50 \\
11 \\
35\end{array}$ & $\begin{array}{r}0 \\
2 \\
53\end{array}$ & $\begin{array}{r}0 \\
7 \\
78\end{array}$ \\
\hline $\begin{array}{l}\text { Student's t test } \\
\text { Normal } v \text { bone } \\
\text { Normal } v \text { liver } \\
\text { Bone } v \text { liver }\end{array}$ & & \multicolumn{2}{|c|}{$\begin{array}{l}P<0.01 \\
N S \\
P<0.05\end{array}$} & \multicolumn{2}{|c|}{$\begin{array}{l}\text { NS } \\
P<0.001 \\
P<0.001\end{array}$} \\
\hline
\end{tabular}

isoenzyme to lipoprotein (Moss, 1962), or it may represent a polymer, since it has been shown that precipitation of the lipoproteins from serum using

Table III Incidence of intestinal and origin bands in the normal, liver, and bone groups

results reported by different workers in that we have shown that both the main band and the origin band are of value in differentiating the elevated serum AP of osteoblastic bone disease from that of hepatic origin. Both the width and the position of the main band effectively separate the bone and liver isoenzymes, but band width appears to provide superior discrimination. Our results also suggest that in normal serum both bone and liver AP are present, the fast band (I) arising from liver and the slow band (II) from bone.

Our gel filtration results confirm the previous finding of Dunne et al (1967) that the origin band consists of a large 19S protein-like molecule which is fairly specific for liver disease. This macromolecule may be a complex formed by the linkage of an AP

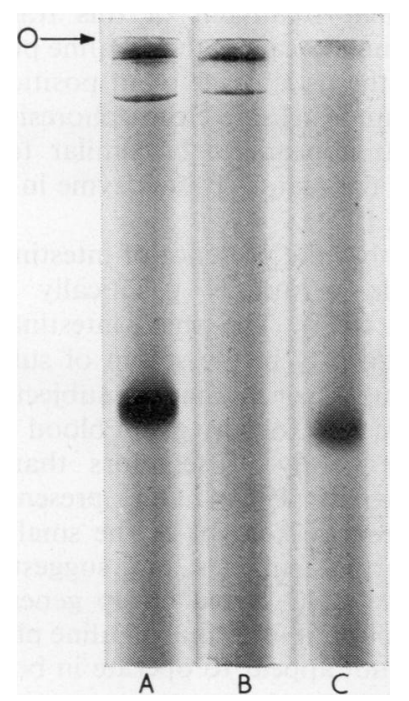

Fig 3 Electrophoresis of the two peaks of alkaline phosphatase activity obtained by gel filtration in liver disease: (A) before gel filtration; (B) after gel filtration: 19S peak; (C) after gel filtration: $7 S$ peak (O marks the origin). 


\begin{tabular}{|c|c|c|c|c|}
\hline \multirow[t]{2}{*}{ Blood Group } & \multicolumn{2}{|c|}{ Normal } & \multicolumn{2}{|c|}{ Bone } \\
\hline & No. & Mean $A P$ & No. & Mean AP \\
\hline $\begin{array}{l}\mathbf{O} \\
\mathbf{B} \\
\mathbf{A B} \\
\mathbf{A}\end{array}$ & $\begin{array}{r}11 \\
4 \\
2 \\
14\end{array}$ & $\begin{array}{l}5 \cdot 37 \\
5 \cdot 70 \\
4 \cdot 50 \\
4 \cdot 18\end{array}$ & $\begin{array}{l}8 \\
2 \\
1 \\
6\end{array}$ & $\begin{array}{l}21 \cdot 79 \\
41 \cdot 15 \\
38 \cdot 00 \\
32 \cdot 57\end{array}$ \\
\hline$t$ test & $\mathbf{O} v \mathbf{A}$ & $P<0.05$ & \multicolumn{2}{|c|}{$\begin{array}{l}\text { O v A not significant } \\
(\mathrm{O}+\mathrm{B}) v \mathrm{~A} \text { not significant }\end{array}$} \\
\hline
\end{tabular}

Table IV Influence of blood group on AP levels in normal and bone groups

(Three normals are included here whose sera were not electrophoresed) AP results are in King-Armstrong units/dl.

\begin{tabular}{|c|c|c|c|c|c|c|}
\hline & \multicolumn{5}{|c|}{ Group } & \multirow[b]{2}{*}{$x^{2}$} \\
\hline & $O$ & $A$ & $\boldsymbol{B}$ & $A B$ & Total & \\
\hline \multicolumn{7}{|l|}{ Normals } \\
\hline $\begin{array}{l}\text { Observed } \\
\text { Expected }\end{array}$ & $\begin{array}{l}11 \\
14 \cdot 5\end{array}$ & $\begin{array}{l}14 \\
12 \cdot 9\end{array}$ & $\begin{array}{l}4 \\
2 \cdot 7\end{array}$ & $\begin{array}{l}2 \\
0.9\end{array}$ & $\begin{array}{l}31 \\
31 \cdot 0\end{array}$ & 2.909 NS \\
\hline \multicolumn{7}{|l|}{ Bone } \\
\hline $\begin{array}{l}\text { Observed } \\
\text { Expected }\end{array}$ & $\begin{array}{l}8 \\
7.9\end{array}$ & $\begin{array}{l}6 \\
7 \cdot 1\end{array}$ & $\begin{array}{l}2 \\
1 \cdot 5\end{array}$ & $\begin{array}{l}1 \\
0 \cdot 5\end{array}$ & $\begin{array}{l}17 \\
17 \cdot 0\end{array}$ & 0.8384 NS \\
\hline \multicolumn{7}{|l|}{ Liver } \\
\hline $\begin{array}{l}\text { Observed } \\
\text { Expected }\end{array}$ & $\begin{array}{l}32 \\
29 \cdot 4\end{array}$ & $\begin{array}{l}22 \\
26 \cdot 3\end{array}$ & $\begin{array}{l}5 \\
5 \cdot 4\end{array}$ & $\begin{array}{l}4 \\
1.9\end{array}$ & $\begin{array}{l}63 \\
63 \cdot 0\end{array}$ & 3.2837 NS \\
\hline
\end{tabular}

Table V Comparison of observed and expected distribution of blood groups in the normal, bone, and liver groups

dextran sulphate has little effect on the activity of this fraction (Dunne et al, 1967). Other workers have shown that treatment of this fraction with n-butanol frequently causes the alkaline phosphatase to migrate to the usual liver band position on subsequent acrylamide gel slab electrophoresis (Jennings et $a l, 1970)$. It appears to be similar to, but not identical with, the main AP isoenzyme in bile (Price and Sammons, 1974).

It is known that the presence of intestinal alkaline phosphatase in serum is genetically controlled (Arfors et al, 1963). The small-intestinal band is seen more frequently in the serum of subjects who are blood group $\mathbf{O}$ or B than in subjects who are blood group $\mathrm{A}$, and for any given blood group it is seen more frequently in secretors than in nonsecretors (Warnes, 1972). Our present findings illustrate the genetic control of the small-intestinal enzyme in normal subjects but suggest that the influence of the $\mathrm{ABO}$ blood group genes in determining the amount of intestinal alkaline phosphatase in serum does not appear to operate in bone disease (table IV). Since, in contrast to normal subjects, patients of blood group A did not have significantly lower levels of alkaline phosphatase than did patients with blood groups $\mathbf{O}$ and $\mathrm{B}$, the mechanism of the reduction in intestinal AP in osteoblastic bone disease is obscure; it may be that an increased secretion of an isoenzyme from one body source can $\overrightarrow{\vec{\sigma}}$ 'switch off' another source of the enzyme. This hypo- thesis is not unreasonable since it has been shown $\overrightarrow{\vec{F}}$ that disease may alter the rate of synthesis of AP at: sites remote from the primary disease process $\frac{}{\circ}$ (Sussman, 1970). It is noteworthy in this context, however, that there was no significant difference in $\vec{\varnothing}$ the mean AP of the bone and liver disease groups, $\frac{\Omega}{q}$ and that no corresponding decrease in the incidence ${ }^{\infty}$ of intestinal bands was found in liver disease. $\overrightarrow{0}$ Furthermore, the decreased incidence of intestinal $\overrightarrow{-}$ bands in bone disease is unlikely to be genetically ${ }_{\sigma}$ determined since the distribution of blood groups in the patients with bone disease was the same as in the? normal subjects and patients with liver disease, and 0 the observed distribution of blood groups within the bone disease group did not differ from the predicted distribution (table V).

Small-intestinal alkaline phosphatase passes into ${ }^{\circ}$ the blood stream after a fatty meal, and blood $\vec{\infty}$ samples in all three groups were therefore taken at a $\mathbb{D}$ standard time of two hours after a meal.Consequently $\underset{\mathbb{D}}{\overrightarrow{0}}$ it is unlikely that the decreased incidence of intestinal bands in bone disease is of dietary origin. Since $\subseteq$ intestinal alkaline phosphatase is known to play an $\vec{\omega}$ active role in the absorption of oleic acid (Linscheor et al, 1971) it would be of interest to know whether the absorption of long chain fatty acids is reduced patients with osteoblastic bone disorders. The finding of decreased amounts of small-intestinal alkalineo phosphatase in patients with osteoblastic boneő disorders is of great interest in view of the recent $\stackrel{\Phi}{ }$ discovery that the intestinal isoenzyme is concerned $\vec{O}$ in calcium absorption (Haussler et al, 1970). The 3 intestinal tract of many species is known to contain? a phytate-splitting enzyme, which is probably non-? specific alkaline phosphatase, the activity of which depends on cholecalciferol status (Wills, 1973). Since the presence of phytic acid in the diet reduces 3 . the availability of calcium for absorption by the precipitation of insoluble calcium salts within the $\frac{}{3}$ lumen of the intestine, and phytic acid binds calcium as a complex (Søgnen, 1964), our finding of low? levels of intestinal alkaline phosphatase in serum in $\frac{}{3}$ osteoblastic bone disease may imply an associated malabsorption of calcium in these patients due to $N$ inability to split phytate.

We acknowledge the support of Professor H. T. $\mathcal{W}$ Howat during this project. We thank Professor S. W. Stanbury and physicians of the Manchestefo Royal Infirmary for access to their patients with bone disease; Mr D. Cunliffe of the Blood Trans-fusion Laboratory, MRI, for the determination of $\frac{0}{0}$ blood groups and secretor status; Dr R. Ollerenshaw 
and the Department of Medical Illustration, MRI, for preparation of the photographs and diagrams; Mrs C. Howland of the MRC Statistics Unit, Gower Street, London, for statistical assistance; and Mrs D. Riley for secretarial help.

\section{References}

Afonja, A. O. and Baron, D. N. (1974). Plasma alkaline phosphatase isoenzymes in hepatobiliary disease. J. clin. Path., 27, 916-920.

Arfors K. E., Beckman, L., and Lundin, L. G. (1963). Genetic variations of human serum phosphatases. Acta genet. (Basel), 13, 89-94.

Chiandussi, L., Greene, S. F., and Sherlock, S. (1962). Serum alkaline phosphatase fractions in hepato-biliary and bone diseases. Clin. Sci., 22, 425-434.

Dacie, J. V. and Lewis, S. M. (1968). Practical Haematology, 4th ed., p. 443. Churchill, London.

Dunne, J., Fennelly, J. J., and McGeeney, K. (1967). Separation of alkaline phosphatase enzymes in human serum using gel filtration (Sephadex G-200) techniques. Cancer (Philad.), 20, 71-76.

Dunsford, I. and Bowley, C. C. (1967). Techniques in Blood Grouping, 2nd edition, vol. II, p. 359. Oliver and Boyd, Edinburgh and London.

Fishman, W. H., Inglis, N. I., and Krant, M. J. (1965). Serum alkaline phosphatase of intestinal origin in patients with cancer and with cirrhosis of the liver. Clin. chim. Acta, 12, 298-303.

Haussler, M. R., Nagode, L. A. and Rasmussen, H. (1970). Induction of intestinal brush border alkaline phosphatase by vitamin $\mathrm{D}$ and identity with Ca-ATPase. Nature (Lond.), 228, 1199-1201.

Jennings, R. C., Brocklehurst, D., and Hirst, M. (1970). A comparative study of alkaline phosphatase enzymes using starch-gel electrophoresis and Sephadex gel-filtration with special reference to high molecular weight enzymes. Clin. chim. Acta, 30, 509-517.

Kaplan, M. M. and Rogers, L. (1969). Separation of human serum-alkaline-phosphatase isoenzymes by polyacrylamide gel electrophoresis. Lancet, 2, 1029-1031.

Kind, P. R. N. and King, E. J. (1954). Estimation of plasma phosphatase by determination of hydrolysed phenol with amino-antipyrine. J. clin. Path., 7, 322-326.

Kopeć, A. C. (1970). The Distribution of the Blood Groups in the United Kingdom. Oxford University Press, London.

Langman, M. J. S., Leuthold, E., Robson, E. B., Harris, J., Luffman, J. E., and Harris, H. (1966). Influence of diet on the 'intestinal' component of serum alkaline phosphatase in people of different $\mathrm{ABO}$ blood groups and secretor status. Nature (Lond.), 212, 41-44.

Linscheer, W. G., Malagelada, J. R., and Fishman, W. H. (1971). Diminished oleic acid absorption in man by Lphenylalanine inhibition of an intestinal phosphohydrolase. Nature (New Biol.), 231, 116-117.

Moss, D. W. (1962). Iso-enzymes of alkaline phosphatase in autolysed and butanol-extracted liver preparations. Nature (Lond.), 193, 981-982.

Newton, M. A. (1967). The clinical application of alkaline phosphatase electrophoresis. Quart. J. Med., 36, 17-28.

Price, C. P. and Sammons, H. G. (1974). The nature of the serum alkaline phosphatases in liver diseases. J. clin. Path., 27, 392-398

Smith, I., Lightstone, P. J., and Perry, J. D. (1968). Separation of human tissue alkaline phosphatases by electrophoresis on acrylamide disc gels. Clin. chim. Acta, 19, 499-505.

Søgnen, E. (1964). Calcium binding substances and intestinal absorption. Sodium phytate. Acta pharmacol. (Kbh.), 21, suppl. I, 13-14.

Sussman, H. H. (1970). Source of the increased serum alkaline phosphatases activity in Paget's disease. Clin. chim. Acta, 27, 121-124.

Sussman, H. H., Small, P. A., Jr., and Cotlove, E. (1968) Human alkaline phosphatase: immunochemical identification of organ-specific isoenzymes. J. biol. Chem., 243, 160-166.

Walker, A. W. and Pollard, A. C. (1971). Observations on serum alkaline phosphatase electrophoretic patterns on polyacrylamide gel. Clin. chim. Acta, 34, 19-29.

Warnes, T. W. (1972). Alkaline phosphatase. Gut, 13, 926-937.

Wills, M. R. (1973). Intestinal absorption of calcium. Lancet, $1,820-823$ 